\title{
The Fibrinolytic System in the Hemolytic Uremic Syndrome: In Vivo and In Vitro Studies
}

\author{
NICOLE C. A. J. van de KAR, VICTOR W. M. van HINSBERGH, EMILE J. P. BROMMER, \\ AND LEO A. H. MONNENS \\ Gaubius Laboratory, IVVO-TNO, Leiden, The Netherlands IN.C.A.J.v.d.K., V.W.M.v.H., \\ E.J.P.B./, and Pediatric Department, Sint Radboud Hospital, Nijmegen, The Netherlands \\ |N.C.A.J.v.d.K., L.A.H.M.|
}

\section{ABSTRACT}

Fibrinolytic parameters and von Willebrand factor (vWF) antigen were measured in the plasma of 10 patients with hemolytic uremic syndrome (HUS). Samples were taken at presentation and again 2 wk later, before and after infusion of 1-desamino-8-arginine vasopressin. Compared with the plasma values of healthy control children, levels of tissue-plasminogen activator ( $t$-PA) antigen, plasminogen activator inhibitor type I (PAI-1) activity, and VWF as well as fibrin(ogen) degradation products were significantly elevated in the plasma of HUS patients on admission. No response of the fibrinolytic parameters and $v W F$ were seen when 1-desamino-8-arginine vasopressin infusion was given on admission. After $2 \mathrm{wk}, \mathrm{t}-\mathrm{PA}$ antigen and $\mathrm{vWF}$ had partially returned to basal values, and t-PA antigen increased rapidly again after 1-desamino-8-arginine vasopressin infusion. To investigate whether verocytotoxin contributes to the alteration of the fibrinolytic system found in HUS patients, purified verocytotoxin-1 (VT-1) was added to the media of cultured human endothelial cells. Addition of VT- 1 alone did not change the production of t-PA, plasminogen activator inhibitor type $\mathrm{I}$, and $\mathrm{vWF}$ antigen in these cells. However, when the endothelial cells were preincubated with tumor necrosis factor- $\alpha$ to increase the number of VT-1 receptors, VT-1 induced a marked

HUS is characterized by the triad microangiopathic hemolytic anemia, thrombocytopenia, and acute renal failure. The most common form of HUS seen in children is the epidemic form, which is preceded by acute, often bloody, gastroenteritis. Although the exact pathogenesis is not known, it is evident that the endothelium plays a central role. Histopathologic studies of the kidney show swollen endothelial cells that are detached from the glomerular basement membrane and bulging into the lumen of the capillaries, thrombi, and fibrin depositions. These

Received October 13, 1993; accepted February 15, 1994

Correspondence: N. C. A. J. van de Kar, M.D., Gaubius Laboratory, TNOIVVO, P.O. Box 430, 2300 AK Leiden, The Netherlands.

Supported by grants from the Ter Meulen Fonds (the Netherlands) and the Dutch Kidney Foundation (Grant C 90.1021 ). decrease of the synthesis of t-PA, plasminogen activator inhibitor type I, and vWF. This was caused by a decrease in overall protein synthesis in the tumor necrosis factor- $\alpha-$ and VT-1-treated endothelial cells. We conclude from this study that the systemic fibrinolytic parameters measured in the plasma of HUS patients are probably not a direct effect of VT-1 on the endothelium but are sequelae of the disease in which the intestine and the kidney are predominantly affected. (Pediatr Res 36: 257-264, 1994)

\section{Abbreviations}

HUS, hemolytic uremic syndrome

DDAVP, 1-desamino-8-arginine vasopressin

VT-1, verocytotoxin-1

VTEC, verocytotoxin-producing Escherichia coli

vWF, von Willebrand factor

t.PA, tissue-plasminogen activator

PAI-1, plasminogen activator inhibitor type I

u-PA, urokinase

NBCS, newborn calf serum

TDP, total fibrin(ogen) degradation products

FbDP, fibrin degradation products

FgDP, fibrinogen degradation products

TNF- $\alpha$, tumor necrosis factor- $\alpha$

thrombotic obstructions contribute to the acute renal failure in HUS patients (1). Since the beginning of the $80 \mathrm{~s}$, several studies have demonstrated that VTEC are the main cause of the epidemic form of HUS (2). In vitro studies on human endothelial cells have shown that verocytotoxins are able to damage endothelial cells and may lead to inhibition of the protein synthesis in the cell $(3,4)$.

The endothelial cells play an important role in the maintenance of the hemostatic balance in the blood (5). Besides having anticoagulant properties, the endothelial cells also prevent the aggregation of platelets and stimulate fibrinolysis. Endothelial cells are the principal source of t-PA in the blood. In addition, they synthesize and secrete PAI-1 (6). PAI-1 can also be liberated from platelets, but the platelet PAI activity is rather low and only 
contributes to a minor degree to a prolonged elevation of PAI activity in the circulating blood (7). Endothelial cells not only provide circulating t-PA under resting conditions, but they can also rapidly release t-PA upon stimulation by various agents including DDAVP. This results in a marked increase in the fibrinolytic capacity of the blood (8) and is also accompanied by a marked, transient release of vWF antigen from endothelial storage sites (9). In addition to the increase in circulating t-PA and vWF, the u-PA concentrations also rapidly increase in plasma after DDAVP infusion (10). The mechanisms by which DDAVP causes increases in t-PA, u-PA, and vWF are not completely understood, but it is likely that extrarenal V2-like receptors are involved in the effects of DDAVP (11).

The role of the fibrinolytic system in HUS has recently been highlighted by the report of Bergstein et al. (12), who suggest that a decrease in PAI-1 antigen during peritoneal dialysis in HUS patients contributes to the recovery of the patients. To get a better insight into the fibrinolytic system in HUS patients and to see whether the regulation of the production of the fibrinolytic proteins by the endothelial cell is disturbed, we have measured fibrinolytic parameters in plasma samples taken on admission and after 2 to $3 \mathrm{wk}$ (convalescent phase) before and after stimulation with DDAVP. In addition, we have investigated whether verocytotoxin contributes to the change in the circulating fibrinolytic proteins and vWF. To that end, we have examined whether human endothelial cells in culture change their synthesis of fibrinolytic proteins when they are incubated with purified VT-1.

\section{METHODS}

Patients. Ten children (five females and five males; mean age, $27.2 \pm 16 \mathrm{mo}$; range, $6.5-52.5 \mathrm{mo}$ ) were diagnosed as having HUS based on the presence of hemolytic anemia with burr cells in the peripheral blood smear, renal failure, and thrombocytopenia (13). HUS was preceded by diarrhea, usually blood stained. Seven patients needed peritoneal dialysis, which ranged from 1 to $10 \mathrm{~d}$ (mean $5.3 \pm 3.3 \mathrm{~d}$ ). In the blood of eight of these 10 patients, antibodies were detected against the most common VTEC serotype O157-O-antigen, indicating an infection with VTEC (14). In the feces of one of the other two patients, VTEC serotype $0157: \mathrm{H} 7$ was isolated. The main laboratory indexes of the patients are displayed in Table 1. In the first morning after admission to the hos- pital, before dialysis was undertaken, $0.3 \mu \mathrm{g} / \mathrm{kg}$ body weight DDAVP, diluted in $100 \mathrm{~mL}$ of saline, was administered i.v. over a period of $30 \mathrm{~min}$. The same DDAVP infusion was given to nine of the 10 HUS patients in the convalescent phase, ranging from 10 to $21 \mathrm{~d}$ after admission ( $14 \pm 4 \mathrm{~d}$, mean $\pm \mathrm{SD}$ ). A 4.5 -mL blood sample was collected immediately before and after the DDAVP infusion. Blood samples were transferred to plastic tubes containing $0.5 \mathrm{~mL}$ of $3.8 \%$ sodium citrate and immediately cooled on melting ice. Platelet-poor plasma, obtained by centrifugation at $4^{\circ} \mathrm{C}$ for $10 \mathrm{~min}$ at $3000 \times \mathrm{g}$, was quickly frozen and stored at $-70^{\circ} \mathrm{C}$ until assays were performed. In the same way, control blood samples were taken from 10 children with chronic renal failure (from six children immediately before the hemodialysis session and four children during peritoneal dialysis). Blood samples from 13 age-matched children in good clinical condition and with no underlying hematologic or renal disease were used as controls. This study was approved by the local Institutional Committee of the Department of Pediatrics and carried out according to the guidelines of the Institutional Review Board of the Sint Radboud Hospital in Nijmegen, the Netherlands.

Materials. DDAVP (Minrin) was obtained from Ferring Pharmaceuticals AB (Malmö, Sweden). Purified VT-1 was prepared in the laboratory of Dr. M. A. Karmali, Toronto, Canada (1.2 $\mathrm{mg}$ of protein $/ \mathrm{mL} ; \mathrm{CD}_{50}$ vero cells: titer $\left.10^{-8}-10^{-9} \mathrm{M}\right)(15)$. Endotoxin content of the VT-1 preparation was $<0.05$ endotoxin units $/ \mathrm{mL}$ by Limulus amoebocyte lysate assay (E-Toxic, Sigma Chemical Co., St. Louis, MO) at a detection level of $0.05-0.1$ endotoxin units/mL. MAb PH1 against VT-1 was a generous gift from Dr. C. Lingwood, Department of Microbiology, Hospital for Sick Children, Toronto, Canada. M199 medium supplemented with $20 \mathrm{mmol} / \mathrm{L} N$-2-hydroxyethylpiperazine- $N^{\prime}$-2-ethanesulfonic acid was obtained from Flow Laboratories (Irvine, Scotland); tissue culture plastics were from Costar (Cambridge, MA). A crude preparation of endothelial cell growth factor was prepared from bovine brain as described by Maciag et al. (16). Human serum was obtained from the local blood bank and was prepared from fresh blood of healthy donors, pooled, and stored at $4^{\circ} \mathrm{C}$; it was not heat inactivated before use. NBCS and FCS were from GIBCO (Grand Island, NY) and Boehringer Mannheim (Mannheim, Germany), respectively; they were heat inactivated before use (at $56^{\circ} \mathrm{C}$ for $30 \mathrm{~min}$ ). Heparin was purchased from Leo Pharma-

Table 1. Laboratory indexes of patients known to have HUS*

\begin{tabular}{lcc}
\hline & On admission $(n=10)$ & Convalescent phase $(n=9)$ \\
\hline $\mathrm{Hb}(\mathrm{mmol} / \mathrm{L})$ & $4.5 \pm 1.0(3.4-6.5)$ & $5.4 \pm 0.7(4.5-6.4)$ \\
Platelets $\left(\times 10^{4} / \mathrm{L}\right)$ & $63 \pm 59(23-203)$ & $398 \pm 159(171-652)$ \\
Leukocytes $\left(\times 10^{9} / \mathrm{L}\right)$ & $17.2 \pm 8.2(7.6-33.8)$ & $8.4 \pm 2.5(5.5-12.5)$ \\
Urea $(\mathrm{mmol} / \mathrm{L})$ & $38 \pm 17(12-63.9)$ & $6.3 \pm 1.7(3.9-9.6)$ \\
Creatinin $(\mu \mathrm{mol} / \mathrm{L})$ & $386 \pm 265(139-928)$ & $60 \pm 14(44-84)$ \\
Fibrinogen $(\mathrm{g} / \mathrm{L})$ & $3.1 \pm 1(1.5-4.6)$ & Not determined \\
Presence of VTEC infection & 9 patients & \\
\hline
\end{tabular}

\footnotetext{
* Values are mean $\pm \mathrm{SD}$ with range in parentheses.
} 
ceuticals (Weesp, the Netherlands). Penicillin/streptomycin was from Boehringer Mannheim. Human fibronectin was a gift of J. A. van Mourik, Central Laboratory of the Red Cross Blood Transfusion Service (Amsterdam, the Netherlands). Human recombinant TNF- $\alpha$ was a gift from Jan Tavernier (Biogent, Ghent, Belgium). The TNF- $\alpha$ preparation contained $2.45 \times 10^{-7} \mathrm{U} / \mathrm{mg}$ protein and less than $40 \mathrm{ng}$ of lipopolysaccharide per $\mathrm{mg}$ of protein. ${ }^{35} \mathrm{~S}$-methionine was purchased from Amersham (Amersham, Buckingshamshire, UK).

Isolation and culture of cells. Endothelial cells from human umbilical vein were isolated by collagenase treatment (17), cultured, and characterized as previously described (18); endothelial cells from human foreskin were isolated and characterized as described (19). The tissues for isolation of endothelial cells were obtained according the guidelines of the Institutional Ethical Committee of the Academic Hospital and St. Elisabeth Hospital in Leiden, the Netherlands. The endothelial cells were seeded in fibronectin-coated $10-\mathrm{cm}^{2}$ wells and cultured in M199 medium supplemented with $20 \mathrm{mmol} / \mathrm{L} \mathrm{N}-2$ hydroxyethylpiperazine- $N^{\prime}$-2-ethanesulfonic acid $(\mathrm{pH}$ 7.4), $10 \%$ human serum, $10 \% \mathrm{NBCS}, 2 \mathrm{mmol} / \mathrm{L}$ L-glutamine, $5 \mathrm{U} / \mathrm{mL}$ heparin, and $150 \mu \mathrm{g} / \mathrm{mL}$ crude preparation of endothelial cell growth factor under $5 \% \mathrm{CO}_{2}$ and $95 \%$ air at $37^{\circ} \mathrm{C}$. When the cells reached confluence, they were detached by trypsin/EDTA and seeded in $2-\mathrm{cm}^{2}$ fibronectin-coated dishes with a split ratio of $1: 3$. The medium was renewed every 2 or $3 \mathrm{~d}$. The cells in the experiments were used after two to four passages. Experiments of endothelial cells from umbilical cord and foreskin used in this study were isolated from three different donors.

In vitro experiments. For the experiments, cells were released with trypsin/EDTA, seeded in a split ratio of $1: 3$ in $2-\mathrm{cm}^{2}$ fibronectin-coated plates, and cultured in complete culture medium ( $400 \mu \mathrm{L} /$ well). In the culture medium, $20 \%$ FCS was used instead of $10 \%$ human serum and $10 \%$ NBCS, because neutralizing activity of NBCS was found against VT-1 and because of potential neutralizing activity against VT-1 in human pooled serum. When confluence was reached, medium was renewed and the cells were preincubated for $24 \mathrm{~h}$ with or without TNF- $\alpha$. After this preincubation period, media were renewed and media with or without VT-1 (17 pmol/L-17 nmol/L) were added. Twenty-four $h$ later the media above the cells were collected and centrifuged, and the supernatant was stored at $-20^{\circ} \mathrm{C}$ until fibrinolytic assays were performed. The cells were washed with M199 medium and released with trypsin/ EDTA. The cells were diluted with 1:1 trypan blue dye solution and counted in a hemocytometer. Those cells that did not absorb trypan blue dye were recognized as viable cells. The experiments were done in duplicate wells.

Protein synthesis was determined by assay of the incorporation of ${ }^{35} \mathrm{~S}$-labeled methionine $(0.25 \mu \mathrm{Ci} / \mathrm{mL}$ added to complete culture medium) in ${ }^{35} \mathrm{~S}$-labeled proteins during a 24-h incubation period. After incubation, the cells were washed and the cellular ${ }^{35} \mathrm{~S}$-labeled proteins were precipitated by adding $10 \%$ trichloroacetic acid. Precipitated radioactivity was dissolved in $0.3 \mathrm{~mL}$ of $0.3 \mathrm{~mol} / \mathrm{L} \mathrm{NaOH}$ and counted in a liquid scintillation counter. Protein was determined according to the method of Lowry using BSA as a standard (20).

Fibrinolytic assays. Assay of t-PA antigen was performed with the ELISA Thrombonostika t-PA from Organon Teknika (Turnhout, Belgium) as described by Bos et al. (21). PAI-1 antigen in the patients' sera was determined using the commercially available TintElize PAI-1 kit from Biopool (Umeå, Sweden). For the in vitro assays, the Immulyse ELISA from Biopool was used. For the U-PA antigen determination, a sandwich ELISA was used as described by Binnema et al. (22). The assay measures the U-PA antigen present in plasma, irrespective of molecular form, i.e. single-chain u-PA, active u-PA, and u-PA in complex with inhibitors. The plasminactivatable single-chain u-PA was measured with a biologic immunoassay (23). PAI activity was determined by a titration method with purified t-PA. Residual activity of t-PA was measured with a spectrophotometric assay, and the inhibitor activity was calculated from the amount of t-PA inhibited as described by Verheijen et al. (24). vWF antigen was measured with a modified ELISA adapted from Dr. J. Ingerslev, using pooled plasma from healthy donors as a reference $(=100 \%)(25)$. Fibrinogen was measured with the chronometric assay as described by Clauss (26). TDP, FbDP, and FgDP were measured with the sandwich-type enzyme immunoassays Fibrinostika TDP, Fibrinostika FbDP, and Fibrinostika FgDP, respectively, from Organon Teknika (Boxtel, the Netherlands). The data of TDP, FbDP, and FgDP are expressed as $\mathrm{mg}$ of fibrinogen equivalent unit/L (27). All measurements were done in duplicate.

Statistical analysis. Results are expressed as mean \pm SD. The significance of differences between the different groups of patients was determined by using the MannWhitney test. The Wilcoxon test was performed for paired data when the fibrinolytic parameters before and after DDAVP infusion in HUS patients were compared. Pearson's coefficient correlation test was used to determine the correlations between fibrinolytic parameters, clinical severity, and laboratory indexes.

\section{RESULTS}

Patients. Table 2 summarizes fibrinolysis parameters and VWF antigen values in the blood of children with HUS, children with chronic renal failure, and children with no underlying hematologic or renal disease (control children). Basal values of t-PA antigen were lower in control children $(2.8 \pm 1.5 \mu \mathrm{g} / \mathrm{L})$ than in healthy adults $(6.4 \pm 2.3 \mu \mathrm{g} / \mathrm{L})(21)$. These observations resemble the recently published fibrinolytic parameters measured in plasma of children by Andrew et al. (28). Basal values of u-PA antigen were higher in control children $(4.9 \pm 1.2$ $\mu \mathrm{g} / \mathrm{L})$ than in adults $(3.5 \pm 1.2 \mu \mathrm{g} / \mathrm{L})(23)$; basal values of vWF antigen and PAI-1 antigen were comparable to those in adults (29). In accordance with other studies 
Table 2. Fibrinolytic parameters and vWF measured in plasma of patients with HUS*

\begin{tabular}{lcccc}
\hline \multicolumn{1}{c}{ Parameter } & $\begin{array}{c}\text { HUS }(n=10) \\
\text { Admission }\end{array}$ & HUS $(n=9)$ & & \\
Convalescent & CRF $(n=10)$ & Control $(n=13)$ \\
\hline t-PA antigen $(\mu \mathrm{g} / \mathrm{L})$ & $9.2 \pm 3.9$ & $4.5 \pm 1.3 \dagger$ & $2.5 \pm 2.3 \ddagger$ & $2.8 \pm 1.5 \ddagger$ \\
PAI-1 antigen $(\mu \mathrm{g} / \mathrm{L})$ & $68 \pm 75$ & $21 \pm 6$ & $27 \pm 21$ & $29 \pm 13$ \\
PAI activity $\left(\mathrm{IU} \times 10^{3} / \mathrm{L}\right)$ & $14.8 \pm 11.4$ & $5.2 \pm 1.8 \dagger$ & $5.9 \pm 2.6 \ddagger$ & $3.4 \pm 0.8 \ddagger$ \\
u-PA antigen $(\mu \mathrm{g} / \mathrm{L})$ & $5.2 \pm 1.8$ & $5.8 \pm 1.2$ & $5.6 \pm 1.7$ & $4.9 \pm 1.2$ \\
scu-PA $(\mu \mathrm{g} / \mathrm{L})$ & $2.5 \pm 0.7$ & $3.2 \pm 0.5 \dagger$ & $1.1 \pm 1.3$ & $3.2 \pm 0.6$ \\
vWF $(\%$ of pooled plasma) & $311 \pm 92$ & $166 \pm 87 \dagger$ & $180 \pm 69 \S$ & $105 \pm 62 \ddagger$ \\
TDP $(\mathrm{mg} / \mathrm{L})$ & $11 \pm 8$ & $6.7 \pm 6.7$ & $0.9 \pm 1.3 \S$ & $0.26 \pm 0.20 \ddagger$ \\
FbDP $(\mathrm{mg} / \mathrm{L})$ & $3.9 \pm 1.9$ & $1.5 \pm 1.3 \pm$ & $0.9 \pm 1.9 \S$ & $0.07 \pm 0.05 \ddagger$ \\
FgDP $(\mathrm{mg} / \mathrm{L})$ & & $0.5 \pm 1.0 \ddagger$ & $0.07 \pm 0.09 \ddagger$ \\
\hline
\end{tabular}

* The data of HUS patients on admission (mean \pm SD) are compared with data from the same patients 2 or 3 wk after admission (convalescent phase), with those of patients with chronic renal failure (CRF), and with those of the control group with no hematologic and nephrologic problems. To determine significant changes in the HUS patients, paired data obtained on admission and in the convalescence phase were compared with the Wilcoxon test. To compare the data of different groups of patients, the Mann-Whitney test was used. scu-PA, single-chain urokinase.

$+p<0.05$ compared with data on admission.

$\ddagger p<0.001$ compared with the HUS group on admission.

$\S p<0.01$ compared with the HUS group on admission.

$\| p<0.01$ compared with data on admission.

(30), elevated vWF concentrations were found in children with acute and chronic renal failure.

The plasma of HUS patients on admission had significantly elevated levels of t-PA antigen, vWF antigen, and PAI activity compared with control children. PAI activity correlated very well with PAI-1 antigen $(r=0.71$, Pearson's coefficient correlation). t-PA antigen levels measured from plasma taken on admission showed moderate correlation with PAI- 1 antigen and $\mathrm{VWF}(r=0.67$ and $r=$ 0.59 , respectively; Pearson's coefficient correlation). No correlation was found for the fibrinolytic parameters and the clinical severity, white blood cell count, platelets, or leukocytes. Only vWf antigen correlated with the amount of white blood cells on admission.

After 2 to $3 \mathrm{wk}$ of hospitalization, the increases in t-PA antigen and vWF antigen were reduced by about $75 \%$, and the PAI-1 antigen levels had been normalized (Fig. 1). In contrast to children with HUS, children with chronic renal failure showed plasma t-PA antigen and PAI- 1 antigen levels similar to those of control children; PAI activity and $v W F$ antigen levels were higher in these patients than in the control group. Elevated levels of TDP, FbDP, and FgDP were detected in the plasma of HUS patients on admission. A decline in these degradation products was seen in the convalescent phase, but the values were not yet entirely normalized (Fig. 1).

The concentration of circulating t-PA, u-PA, and vWF can rapidly be increased by infusion of DDAVP. When DDAVP infusion was given upon admission to the HUS patients, we observed no significant increase in t-PA antigen or VWF antigen in the plasma (Table 3). Neither did the plasma concentration of $\mathrm{u}-\mathrm{PA}$ antigen change in HUS patients during DDAVP infusion. When DDAVP was given to the same patients 2 to 3 wk later during the convalescent phase, an increase in t-PA antigen was found in all patients, whereas no increase was seen for $\mathrm{vWF}$ antigen or u-PA antigen (Table 3 ).

In vitro experiments. It is generally assumed that endothelial damage by verocytotoxins plays a key role in the pathogenesis of the epidemiologic form of HUS. Inasmuch as the prolonged elevations of the plasma t-PA, PAI-1, and vWF levels suggest that the synthesis of these proteins in endothelial cells is enhanced, we examined whether VT-1 changes the production of $\mathrm{t}-\mathrm{PA}$ and PAI-1 by human endothelial cells in vitro. Figure $2 A$ shows that VT-1 did not significantly affect the production of t-PA and PAI- 1 in nonstimulated confluent umbilical vein endothelial cells. To enhance the sensitivity of human umbilical vein endothelial cells for VT-1, we also studied these parameters in endothelial cells that had been preincubated for $24 \mathrm{~h}$ with TNF- $\alpha$. This preincubation causes a marked increase in the expression of VT-1 receptors (4). Under these conditions, VT-1 markedly reduced the synthesis of t-PA and PAI-1 (Fig. 2B). In agreement with the known inhibitory effect of VT-1 on the cellular protein synthesis, a marked decrease in the synthesis of cellular proteins and in the number of cells was observed after incubation with VT-1. Similarly, the production of $\mathrm{vWF}$ antigen decreased after exposure of the cells to TNF- $\alpha$ and VT-1 (not shown). These effects were not found when VT-1 was inactivated by heat treatment before being added to the cells or when VT-1 was preincubated with MAb to VT-1. Similarly, in TNF- $\alpha$-treated human microvascular endothelial cells, VT-1 induced a concentration-dependent decrease in cell number, PAI-1 production, and accumulation of t-PA (Fig. 3 ). These experiments indicate that VT-1 does not induce t-PA, PAI-1, or VWF production but rather decreases their synthesis in endothelial cells by its inhibitory effect on protein synthesis.

\section{DISCUSSION}

In this study, we report on the fibrinolytic parameters and VWF antigen in plasma of HUS patients, patients with chronic renal failure, and healthy children.

Elevated levels of t-PA antigen and PAI activity were found in the plasma of HUS patients on admission. These findings correspond with the recent observations in 

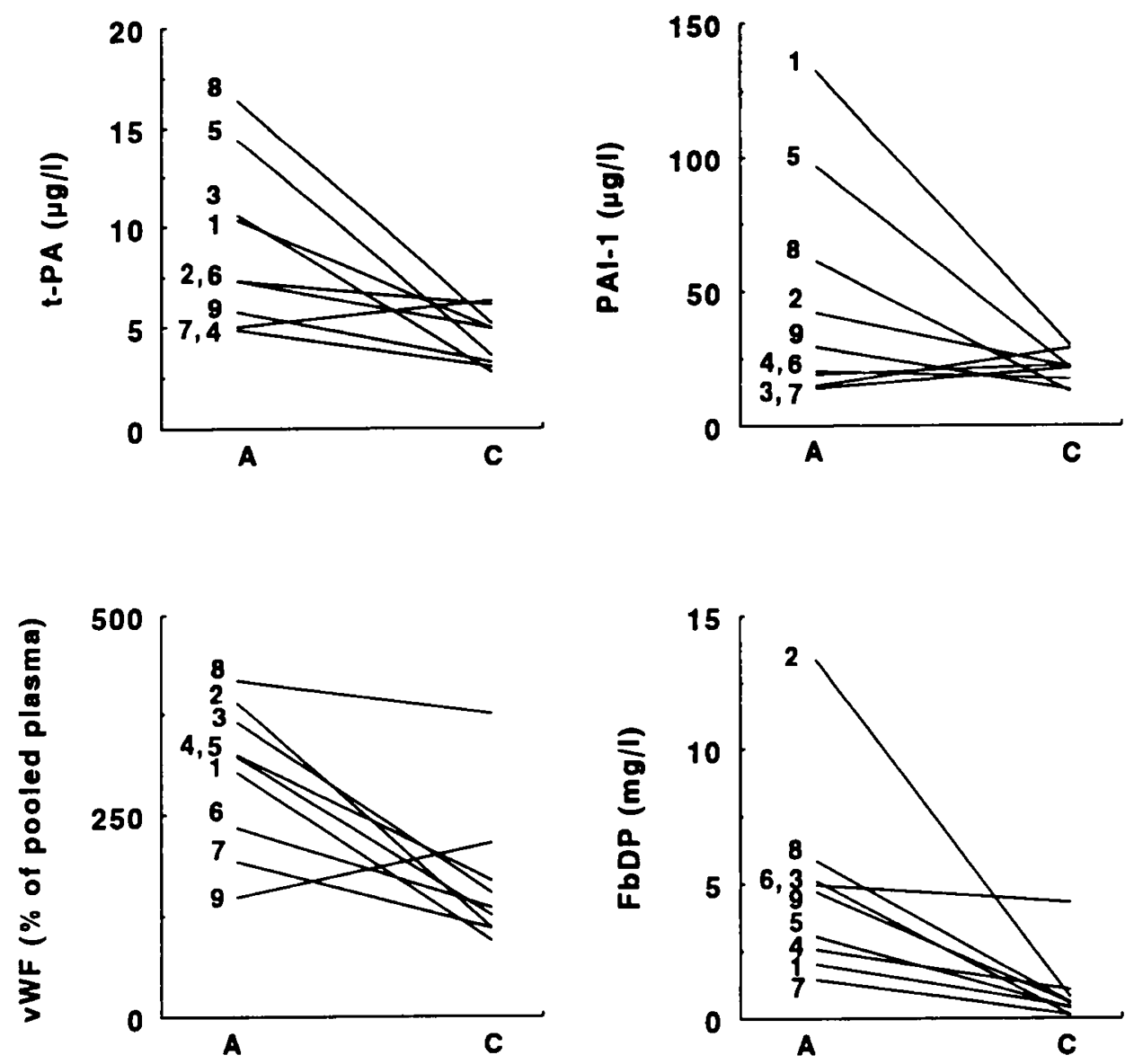

Figure 1. $t-P A$ antigen, PAI- 1 antigen, vWF antigen, and FbDP measured in the plasma of nine HUS patients, individually indicated by numbers. Measurements were done in plasma taken on admission $(A)$ and in the convalescent phase of HUS $(C)$.

thrombotic thrombocytopenic purpura and HUS patients by Monteagudo et al. (31). Simultaneously the plasma vWF concentration was enhanced. Elevated FbDP or FgDP found in the plasma on admission indicate that there is a systemic fibrinogenolysis and fibrinolysis secondary to an activated state of coagulation.

Nowadays it has become clear that VTEC infection is the major cause of the epidemic form of HUS. In nine HUS patients, we found evidence for a VTEC infection (14). Verocytotoxin can cause endothelial cell damage, which is the predominant feature of the glomeruli in the kidneys of patients with HUS. We demonstrated that addition of VT-1 to human endothelial cells that con- tained sufficient VT-1 receptors [as induced here by TNF- $\alpha$ pretreatment (4)] causes a decrease in the production of t-PA and PAI-1 antigens probably caused by an inhibitory effect of VT-1 on overall protein synthesis. Such inhibition of protein synthesis has also recently been observed in renal endothelial cells (32).

The t-PA, PAI-1, and vWF levels were elevated in the plasma of HUS patients on admission. This suggests that, in addition to hemorrhagic colitis and kidney failure, HUS patients display a general activation of the vascular endothelium. A similar pattern of elevated levels of $t-P A$, PAI-1, and VWF has been observed in the plasma of patients with sepsis, during which endotoxins and endog-

Table 3. Effect of DDAVP on fibrinolytic parameters and $v W F$ measured in plasma of patients with HUS*

\begin{tabular}{|c|c|c|c|c|}
\hline \multirow[b]{2}{*}{ Parameter } & \multicolumn{2}{|c|}{ HUS $(n=10)$ on admission } & \multicolumn{2}{|c|}{ HUS $(n=9)$ convalescent phase } \\
\hline & Before DDAVP & After DDAVP & Before DDAVP & After DDAVP \\
\hline t-PA antigen $(\mu \mathrm{g} / \mathrm{L})$ & $9.2 \pm 3.9$ & $10.9 \pm 5.0$ & $4.5 \pm 1.3$ & $8.0 \pm 3.3 \dagger$ \\
\hline PAI-1 antigen $(\mu \mathrm{g} / \mathrm{L})$ & $68 \pm 75$ & $44 \pm 51$ & $21 \pm 6$ & $17 \pm 7$ \\
\hline PAI activity $\left(\mathrm{IU} \times 10^{3} / \mathrm{L}\right)$ & $15 \pm 11$ & $20 \pm 27$ & $5.2 \pm 1.8$ & $4.0 \pm 1.4$ \\
\hline u-PA antigen $(\mu \mathrm{g} / \mathrm{L})$ & $5.2 \pm 1.8$ & $5.6 \pm 1.4$ & $5.8 \pm 1.2$ & $5.0 \pm 0.9$ \\
\hline scu-PA antigen $(\mu \mathrm{g} / \mathrm{L})$ & $2.5 \pm 0.7$ & $2.5 \pm 0.6$ & $3.2 \pm 0.5$ & $2.9 \pm 1.1$ \\
\hline vWF ( $\%$ of pooled plasma) & $311 \pm 92$ & $373 \pm 172$ & $166 \pm 87$ & $211 \pm 100$ \\
\hline
\end{tabular}

* The effect of DDAVP on fibrinolytic parameters and VWF was measured before and after treatment with DDAVP in the acute phase and in the convalescent phase. The data are expressed as mean \pm SD. Statistical analysis of the paired data obtained on admission and in the convalescent phase was performed with the Wilcoxon test. scu-PA, single-chain urokinase.

$\dagger p<0.05$. 
A

Cell viabllity

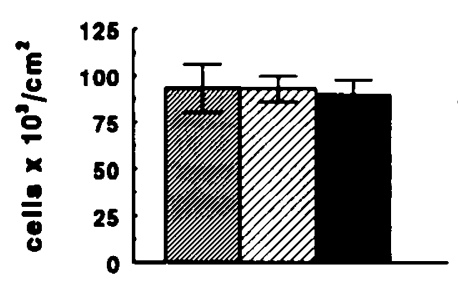

ss-cellular proteins

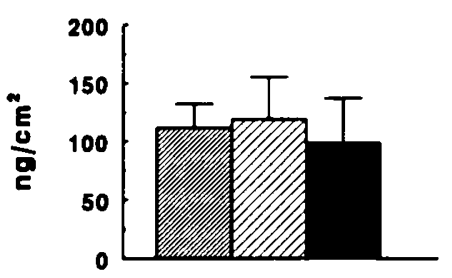

t-PA antigen

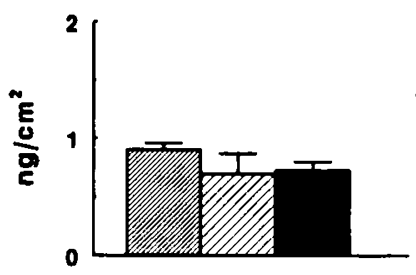

PAl-1 antlgen

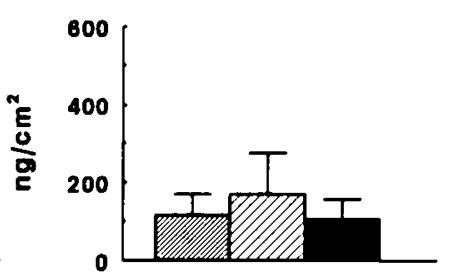

Cell viabllity

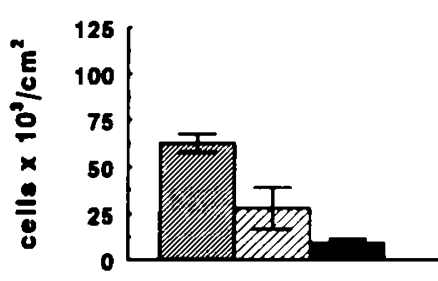

25S-cellular protelns

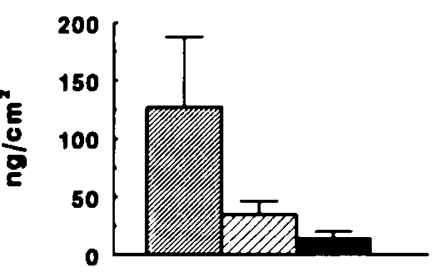

t-PA antigen

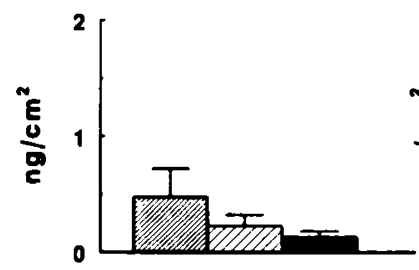

PAl-1 antigen

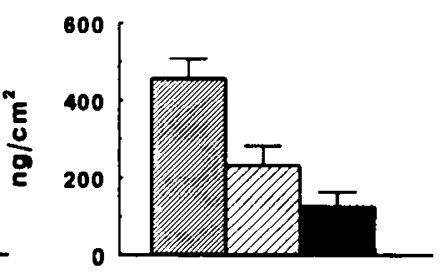

Figure 2. Confluent human umbilical vein endothelial cells in $2-\mathrm{cm}^{2}$ wells were preincubated for $24 \mathrm{~h}$ without $(A)$ or with $(B) 500 \mathrm{U} / \mathrm{mL}$ TNF- $\alpha$ and subsequently incubated in $0.4 \mathrm{~mL}$ of $\mathrm{M} 199-N$-2-hydroxyethylpiperazine- $N^{\prime}$-2-ethanesulfonic acid medium supplemented with $20 \%$ FCS and the same amount of TNF- $\alpha$, together with $17 \mathrm{pmol} / \mathrm{L} \mathrm{VT-1} \mathrm{(hatched} \mathrm{bars)} \mathrm{and} 17 \mathrm{nmol} / \mathrm{L} \mathrm{VT-1}$ (black bars) and without VT-1 (crosshatched bars). The number of cells at the start of the preincubation was $9 \times 10^{4}$ cells $/ \mathrm{cm}^{2}$ for all wells. After preincubation, the number of cells was $9.3 \times 10^{4}$ cells $/ \mathrm{cm}^{2}$ for control cells $(A)$ and $6.3 \times 10^{4}$ cells $/ \mathrm{cm}^{2}$ for TNF- $\alpha$-treated cells $(B)$. Because VT-1 caused cell death during the incubation with VT-1 and TNF- $\alpha$ and thus the number of viable cells changed during the incubation period, the production of $\mathrm{t}-\mathrm{PA}$ and PAI-1 antigens are expressed per $\mathrm{cm}^{2}$. Viability of the cells was determined by trypan blue exclusion test. Other experimental details are given in Methods. Data are expressed as mean \pm SD of three experiments with endothelial cells from different donors.

enous mediators, in particular the inflammatory mediators TNF- $\alpha$ and IL-1, contribute to these alterations (33, 34). TNF- $\alpha$, IL-1, and IL-6 were not elevated in the plasma of patients with a mild form of HUS $(35,36$, unpublished observations), but we observed that they were elevated in patients with a severe form of HUS, i.e. in patients who also developed neurologic complications and pancreas involvement (N. van de Kar, unpublished observations). These data suggest that circulating cytokines may play a role in HUS but are unlikely to be significant in mild forms of HUS. On the other hand, locally produced inflammatory mediators in the kidney of HUS patients may escape detection in plasma because of their short biologic half-life (37). In favor of a local effect of inflammatory mediators, Siegler et al. (36) reported that TNF- $\alpha$ was elevated in the urine of HUS patients. Even if inflammatory mediators contribute locally to the increase of the t-PA, PAI-1, and vWF levels in plasma, it is likely that other factors that are generated in the injured intestines or kidneys are an important cause of the sustained elevation of the t-PA, PAI-1, and vWF concentrations in the blood of HUS patients $(38-40)$.
Cell viability

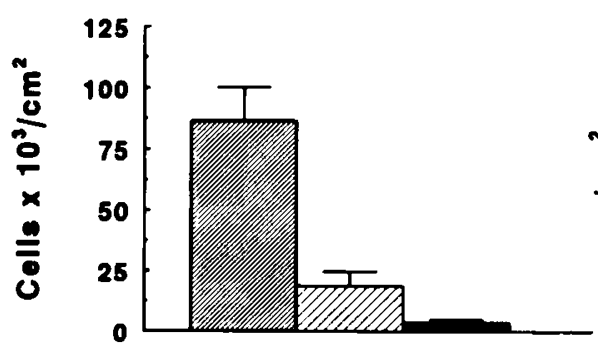

t-PA antigen

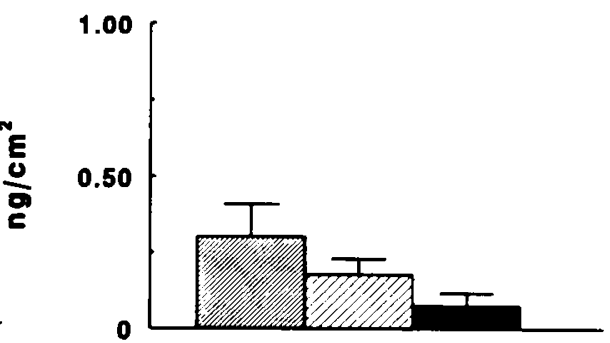

PAl-1 antigen

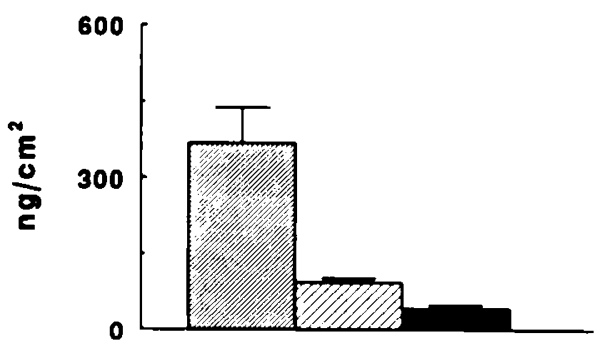

Figure 3. Confluent human foreskin microvascular endothelial cells in $2-\mathrm{cm}^{2}$ wells were preincubated for $24 \mathrm{~h}$ with $500 \mathrm{U} / \mathrm{mL}$ TNF- $\alpha$ and subsequently in $0.4 \mathrm{~mL}$ of M199-N-2-hydroxyethylpiperazine- $N^{\prime}$-2-ethanesulfonic acid medium supplemented with $20 \%$ FCS and the same amount of TNF- $\alpha$, together with $17 \mathrm{pmol} / \mathrm{L}$ VT-1 (hatched bars) and $17 \mathrm{nmol} / \mathrm{L} \mathrm{VT-1} \mathrm{(black} \mathrm{bars)} \mathrm{or} \mathrm{without} \mathrm{VT-1} \mathrm{(crosshatched} \mathrm{bars).} \mathrm{The} \mathrm{number} \mathrm{of} \mathrm{cells}$ after $24 \mathrm{~h}$ of preincubation with TNF- $\alpha$ was $8 \times 10^{4} \mathrm{cells} / \mathrm{cm}^{2}$ for all variables. Because VT-1 caused cell death during the incubation with VT-1 and TNF- $\alpha$ and thus the number of viable cells changed, the production of t-PA and PAI-1 antigens is expressed per $\mathrm{cm}^{2}$. Data given are expressed as mean $\pm \mathrm{SD}$ of three independent experiments. 
Activated leukocytes, which can be found in the peripheral blood in HUS (41), contribute to endothelial activation, and other factors such as activated complement and coagulation factors may be involved (42-45).

In our patients, no release of t-PA, u-PA, and vWF could be evoked by DDAVP infusion on admission. Unresponsiveness to DDAVP cannot be explained entirely by the renal problems seen in HUS, because patients with terminal renal insufficiency and anephric patients can still react to DDAVP infusion $(46,47)$. However, it is well known that patients with kidney diseases respond less pronouncedly to DDAVP than healthy volunteers, and some are nonresponsive $(46,47)$. Unresponsiveness of t-PA and VWF antigen release to DDAVP infusion has also been observed in patients with inflammatory bowel disease (Crohn's disease, ulcerative colitis) who have a normal level of t-PA and vWF before DDAVP infusion (48). It is therefore possible that the lack of response to DDAVP in HUS patients is caused by a simultaneous disturbance of the kidney and the intestine. On the other hand, it is unlikely that the lack of response of t-PA and vWF to DDAVP infusion is caused by the depletion of endothelial storage pools, because the biologic half-life of t-PA is very short and depletion of the t-PA should result in a drop in circulating t-PA. After 2 wk of hospitalization, not only were the plasma levels of t-PA, PAI-1, and vWF antigen normalizing, but also t-PA antigen increased upon DDAVP infusion. This indicates that the activation of the endothelium had decreased and that the response to DDAVP was recovering. It is of interest to note that a DDAVP-induced increase in t-PA antigen was also found in patients recovering from Crohn's disease or ulcerative colitis. Recently, Bergstein et al. (12) reported that elevated levels of PAI-1 during the clinical course were related to a poor outcome. In our study, all patients, including those with a high PAI-1 level on admission, completely recovered.

Although VT-1 causes a decrease of the production of fibrinolytic proteins by endothelial cells in vitro, the plasma levels of these proteins in HUS patients changed in the opposite direction. Although these data seem to be paradoxical, they do not really conflict. We hypothesize that the following events may occur in HUS. After a period of hemorrhagic colitis, the main organ affected in HUS is the kidney. The human kidney contains receptors for verocytotoxin (49), which is generally assumed to contribute to the damage of the endothelium in the glomeruli in the kidney. This damage can lead to a local procoagulant situation. In this condition, thrombin and inflammatory mediators are generated and polymorphonuclear leukocytes are activated, probably causing a general activation of the endothelium at sites distal to the affected areas. This is reflected in the elevated levels of t-PA, PAI-1, and vWF found in the plasma of the HUS patients in the acute phase of the disease. Additional studies will be necessary to prove this hypothesis.

We conclude from this study that the systemic fibrinolytic parameters measured in plasma of HUS patients are probably not a direct effect of VT-1 on the endothelium but are sequelae of the disease in which the kidney and the intestine are predominantly affected.

Acknowledgments. The authors thank Dr. M. A. Karmali and Dr. C. Lingwood (Department of Microbiology, Hospital for Sick Children, Toronto, Canada) for providing us with purified VT-1 and the MAb PH1; Dr. M. Cornelissen for collecting the control samples; Dr. G. Dooijewaard for measuring the u-PA and single-chain u-PA in the plasma samples; and Dr. P. de Knijff for his help with the statistical analysis.

\section{REFERENCES}

1. Kaplan BS, Cleary TG, Obrig TG 1990 Recent advances in understanding the pathogenesis of the hemolytic uremic syndromes. Pediatr Nephrol 4:276-283

2. Karmali MA 1989 Infection by verocytotoxin-producing Escherichia coli. Clin Microbiol Rev 2:15-38

3. Obrig TG. Del Vecchio PJ. Karmali MA, Petric M. Moran TP. Judge TK 1987 Pathogenesis of haemolytic uraemic syndrome. Lancet 2:687

4. Van de Kar NCAJ, Monnens LAH, Karmali MA, van Hinsbergh VWM 1992 Tumor necrosis factor and interleukin-1 induce the expression of the verocytotoxin receptor globotriaosylceramide on human endothelial cells: implications for the pathogenesis of the hemolytic uremic syndrome. Blood 80:27552764

5. Hekman CM, Loskutoff DJ 1987 Fibrinolytic pathways and the endothelium. Semin Thromb Hemost 13:514-527

6. Van Hinsbergh VWM 1988 Regulation of the synthesis and secretion of plasminogen activators and plasminogen activator inhibitor by endothelial cells. Haemostasis 18:307-327

7. Booth NA, Simpson AJ, Croll A, Bennett B, MacGregor IR 1988 Plasminogen activator inhibitor (PAI-1) in plasma and platelets. Br J Haematol 70:327-333

8. Mannucci PM, Rota L 1980) Plasminogen activator response after DDAVP. A clinico-pharmalogical study. Thromb Res 20:69-76

9. Cash JD, Gader AMA, Da Costa J 1974 The release of plasminogen activator and FVIII by LVP, AVP, DDAVP, ATIII, and OT in man. Br J Haematol $27: 363-364$

10. Levi M, ten Cate JW, Dooijewaard G, Sturk A, Brommer EJP, Agnelli G 1989 DDAVP induces systemic release of urokinase-type plasminogen activator. Thromb Haemost 62:686-689

11. Bichet DG, Razi M, Lonergan M, Arthrus MF, Papukna V, Kortas C, Barjon JN 1988 Hemodynamic and coagulation responses to 1-desamino [ $8-D$ arginine] vasopressin in patients with congenital nephrogenic diabetes insipidus. N Engl J Med 318:881-887

12. Bergstein JM, Riley M, Bang NU 1992 Role of plasminogen-activator type 1 in the pathogenesis and outcome of the hemolytic uremic syndrome. $\mathrm{N}$ Engl J Med 327:755-759

13. Fong FS, De Chaderevian JP, Kaplan BS 1982 Haemolytic-uraemic syndrome: current concepts and management. Paediatr Clin N Am 29:835-856

14. Chart H, Rowe B, Van de Kar N, Monnens LAH 1991 Serological identification of Escherichia coli $\mathrm{O} 157$ as cause of haemolytic uraemic syndrome in the Netherlands. Lancet $337: 4.37$

15. Petric M, Karmali MA, Richardson SE, Chung R 1987 Purification and biological properties of Escherichia coli verocytotoxin-1. FEMS Microbiol Lett 41:63-68

16. Maciag T, Cerundolo J, Ilsley S. Kelley PR, Forand R 1979 An endothelial cell growth factor from bovine hypothalamus; identification and partial characterization. Proc Natl Acad Sci USA 76:5674-5678

17. Jaffe E, Nachmann RL, Becker CG, Minick CR 1973 Culture of human endothelial cell derived from umbilical veins. Identification by morphology and immunologic criteria. J Clin Invest 52:2745-2756

18. Van Hinsbergh VWM, Bertina RM, Van Wijngaarden $A$, Van Tilburg NH, Emeis JJ, Haverkate F 1985 Activated protein C decreases plasminogen activator-inhibitor activity in endothelial cell-conditioned medium. Blood $65: 444-451$

19. Van Hinsbergh VWM, Sprengers E, Kooistra T 1987 Effect of thrombin on the production of plasminogen activators and $\mathrm{PA}$ inhibitor-1 by human foreskin microvascular endothelial cells. Thromb Haemost 57:148-153

20. Lowry O, Rosebrough N, Farr A, Randall R 1951 Protein measurement with the Folin phenol reagent. J Biol Chem 193:265-275

21. Bos R, Hoegee-de Nobel E, Laterveer R, Meyer P, Nieuwenhuizen W 1992 A one-step enzyme immunoassay for the determination of total tissue-type plasminogen activator (t-PA) antigen in plasma. Blood Coagul Fibrinolysis 3:303-307

22. Binnema DJ, van Iersel JJL, Dooijewaard G 1986 Quantification of urokinase antigen in plasma and culture media by use of an ELISA. Thromb Res $43: 569-577$ 
23. Dooijewaard G, van Iersel JJL, Brommer EJP 1986 Quantification of pro-UK, UK and UK-inhibitor levels in plasma of patients and healthy man. Fibrinolysis 1(suppl): 142

24. Verheijen JH, Mullaart E, Chang GTG, Kluft C, Wijngaards G 1982 A simple sensitive spectophotometric assay for extrinsic (tissue-type) plasminogen activator applicable to measurements in plasma. Thromb Haemost 48:266-269

25. Tranquille N, Emeis JJ 199() The simultaneous acute release of tissue-type plasminogen activator and von Willebrand factor in the perfused rat hindleg region. Thromb Haemost 63:454-458

26. Clauss A 1957 Gerinnnungsphysiologische Schnellmethode zur Bestimmung des Fibinogens. Acta Haematol 17:237-246

27. Koppert PW, Koopman J, Haverkate F, Nieuwenhuizen W 1986 Production and characterization of a monoclonal antibody reactive with a specific neoantigenic determinant (comprising $B \beta 54: 118$ ) in degradation products of fibrin and of fibrinogen. Blood $68: 437+41$

28. Andrew M, Vegh P, Johnston M, Bowker J, Ofuso F, Mitchell L 1992 Maturation of the hemostatic system during childhood. Blood 80:1998-2005

29. Declerck PJ, Alessi MC, Verstreken M, Kruithof EKO, Juhan-Vague I, Collen D 1988 Measurement of plasminogen activator inhibitor 1 in biological fluids with a murine monoclonal antibody-based enzyme-linked immunosorbent assay. Blood 71:220-225

30. Zwaginga JJ, IJsseldijk MJW, Beeser-Visser N, De Groot PG, Vos J, Sixma JJ $199($ ) High von Willebrand factor concentration compensates a relative adhesion defect in uremic blood. Blood 75:1498-1508

31. Monteagudo J, Pereira A. Reverter JC, Pijoan J, Tusell J, Ordinas A, Castille R 1991 Thrombin generation and fibrinolysis in the thrombotic thrombocytopenic purpura and the hemolytic uremic syndrome. Thromb Haemost 66:515519

32. Obrig TG, Louise CB, Lingwood CA, Boyd B, Maloney LB, Daniel TO 1992 Endothelial heterogeneity in Shiga toxin receptors and responses. J Biol Chem 268:15484-15488

33. Suffredini AF, Harpel PC, Parillo JE 1989 Promotion and subsequent inhibition of plasminogen activation after administration of intravenous endotoxin to normal subjects. N Engl J Med 320:1165-1172

34. van Hinsbergh VWM, Bauer KA, Kooistra T, Kluft C, Dooijewaard G, Sherman ML. Nieuwenhuizen W 1990 Progress of fibrinolysis during tumor necrosis factor infusions in humans. Concomitant increase in tissue-type plasminogen activator, plasminogen activator inhibitor type-1, and fibrin(ogen) degradation products. Blood 76:2284-2289

35. Wada H, Kaneko T, Ohiwa M, Tanigawa M, Tamaki S, Minami N, Takahashi H, Deguchi K, Nakano T 1992 Plasma cytokine levels in thrombotic thrombocytopenic purpura. Am J Hematol 40:167-170
36. Siegler RL, Edwin SS, Christofferson RD, Mitchell MD 1991 Plasma and urinary cytokines in childhood hemolytic uremic syndrome. J Am Soc Nephrol 2:274

37. Jirik FR, Podor TJ, Hirano T, Kishimoto T, Loskutoff DJ, Carson DA, Lotz M 1989 Bacterial lipopolysaccharide and inflammatory mediators augment IL-6 secretion by human endothelial cells. J Immunol 142:144-147

38. Van der Poll T, Büller HR, Ten Cate H, Wortel $\mathrm{CH}$, Bauer KA, van Deventer SJH, Hack CE, Sauerwein HP, Rosenberg RD, Ten Cate JW 199) Activation of coagulation after administration of tumor necrosis factor to normal subjects. N Engl J Med 322:1622-1627

39. Hsueh W, Sun X, Rioja KN, Gonzalez-Crussi F 199) The role of the complement system in shock and tissue injury induced by tumour necrosis factor and endotoxin. Immunology 70):309-314

4). Van der Poll T, Van Deventer SJH, Hack CE, Wolbink GJ, Aareden LA, Büller HR, Ten Cate JW 1992 Effects on leukocytes following injection of tumor necrosis factor into healthy humans. Blood 79:693-698

41. Forsyth KD, Simpson A, Fitzpatrick MM, Barratt TM, Levinsky RJ 1989 Neutrophil mediated endothelial injury in the haemolytic uraemic syndrome. Lancet 2:411-414

42. Monnens L, Molenaar J, Lambert PH, Proesmans W, Van Munster P 1980 The complement system in hemolytic-uremic syndrome in childhood. Clin Nephrol 13:168-171

43. Monnens LAH, Van Aken W, De Jong M 1982 Active intravascular coagu. lation in the epidemic form of the hemolytic uremic syndrome. Clin Nephrol 17:284-287

44. Levine JD, Harlan JM, Harker LA. Joseph ML, Counts RB 1982 Thrombinmediated release of factor VIII antigen from human umbilical endothelial cells in culture. Blood 60:531-5.34

45. Levin EG. Marzec U, Anderson J, Harker LA 1984 Thrombin stimulates tissue plasminogen activator release from cultured human endothelial cells. J Clin Invest 74:1988-1995

46. Brommer EJP, Schicht I, Wijngaards G, Verheijen JH, Rijken DC 1984 Fibrinolytic activators and inhibitors in terminal renal insufficiency and in anephric patients. Thromb Haemost 52:311-314

47. Zeigler ZR, Megaludis A, Fraley DS 1992 Desmopressin (DDAVP) effects on platelet rheology and von Willebrand factor activities in uremia. Am J Hematol 39:90-95

48. Gris JC, Schved JF, Dubois A, Aguilar-Martinez P, Arnaud A Sanchez N Sarlat C, Balm s JL 1990 Impaired fibrinolytic capacity in patients with inflammatory bowel disease. Thromb Haemost 63:472-475

49. Boyd B, Lingwood C 1989 Verocytotoxin receptor glycolipid in human renal tissue. Nephron 51:207-210 